\title{
Tea consumption is inversely related to 5 -year blood pressure change among adults in Jiangsu, China: a cross-sectional study
}

\author{
Xiaoliang Tong ${ }^{1}$, Anne W Taylor ${ }^{2}$, Lynne Giles ${ }^{1}$, Gary A Wittert ${ }^{2}$ and Zumin Shi ${ }^{2,3^{*}}$
}

\begin{abstract}
Background: Data relating to the association between tea consumption and blood pressure change are inconsistent. The aim of this analysis was to investigate the association between tea consumption and the change in blood pressure (BP) in Chinese adults over a 5 -year period.

Methods: Data from 1109 Chinese men $(N=472)$ and women $(N=637)$ who participated in the Jiangsu Nutrition Study (JIN) were analysed. BP was measured in 2002 and 2007. Tea (green, black and total tea) consumption was quantitatively assessed at the follow-up survey in 2007.

Results: Total tea and green tea consumption were inversely associated with 5-year diastolic BP (DBP) but not systolic BP (SBP) change. In the multivariable analysis, compared with no consumption of tea, those with daily total tea/green tea consumption of at least $10 \mathrm{~g}$ had $2.41 \mathrm{mmHg}$ and $3.68 \mathrm{mmHg}$ smaller increase of DBP respectively. There was a significant interaction between smoking and total tea/green tea consumption and DBP change. The inverse association between total tea/green tea consumption and DBP change was significant only in non-smokers. Green tea consumption was inversely associated with SBP change only in non-smokers and those without central obesity.
\end{abstract}

Conclusion: The consumption of green tea is inversely associated with 5-year BP change among Chinese adults, an effect abrogated by smoking.

Keywords: Blood pressure change, Tea consumption, Epidemiology, Nutrition, Population study

\section{Background}

On average, worldwide, approximately $40 \%$ of adults aged 25 and above have hypertension [1]. In China the prevalence of hypertension in adults increased from $27.2 \%$ in 2002 to $33.5 \%$ in 2010 [2], and was comparable in urban and rural areas (34.7\% vs 32.9\%) [3]. Despite the wellestablished associations of hypertension with cardiovascular and renal disease [4-7], only about $19 \%$ of those with hypertension had adequate treatment [2]. Lifestyle factors including smoking, high salt intake, energy dense, low fibre, low fruit and vegetable diets are known risk factors of hypertension [8-11].

\footnotetext{
* Correspondence: zumin.shi@adelaide.edu.au

${ }^{2}$ Discipline of Medicine, The University of Adelaide, 122 Frome Street, Adelaide, SA 5000, Australia

${ }^{3}$ Department of Nutrition and Foodborne Disease Prevention, Jiangsu Provincial Centre for Disease Control and Prevention, 172 Jiangsu Road, Nanjing 210009, China

Full list of author information is available at the end of the article
}

Tea is one of the most commonly consumed beverages worldwide and has a long history of use that originated about 5000 years ago in China. Tea contains a variety of antioxidants and other chemicals (e.g. flavonoids, caffeine, theanine, theaflavins, theophylline, phenolic acids and polyphenols) that have anti-mutagenic, anti-diabetic and anti-inflammatory effects [12-17]. An inverse association between tea consumption and blood pressure (BP) has been reported in cross-sectional epidemiological studies $[13,18,19]$. Experimental interventions in animal and humans suggest beneficial effects of tea on BP [14-17,19-23]. Conversely, some short-term trials in humans have shown a positive association between tea and BP [24-26]. Others have shown no effects [26-28]. A systematic review on five randomized clinical trials concluded that there was no effect of tea consumption on BP [12]. There is no longitudinal study on the association between regular tea consumption and 
$\mathrm{BP}$, and the interactions between tea consumption and other lifestyle factors have not been assessed.

The objective of the study was to assess the association between tea consumption and 5-year BP changes, and the interaction between tea consumption and lifestyle factors in relation to BP changes among Chinese adults aged 20 years and above, based on a large population study in China: The Jiangsu Nutrition Study (JIN).

\section{Methods}

\section{Study population}

The JIN cohort study comprises men and women aged 20 years or older and the methods of sampling have been described previously [29-31]. In 2002, BP was measured in, and dietary information obtained from, 2849 participants living in two cities and six rural areas. In 2007, 1682 of the original participants were identified through household visits: of these 1492 agreed to a follow-up interview at home, with 1282 (76.2\%) participants attending follow-up clinics. For the current analysis, we excluded those participants who had extreme values of weight change of more than $20 \mathrm{~kg}$ and those who had known diabetes, stroke or cancer at baseline $(n=40)$. In addition, 133 participants did not have information on tea consumption in 2007. The final sample size in this study consisted of 472 men and 637 women (total $n=1109$ ) (Figure 1). Compared with the retained participants $(n=1682)$, those lost to follow-up $(n=1167)$ were generally younger, with a higher BMI, waist circumference and lower systolic BP (SBP), but there were no differences in energy intake, Diastolic BP (DBP) or gender (Additional file 1: Table S1). The study was conducted according to the guidelines laid down in the

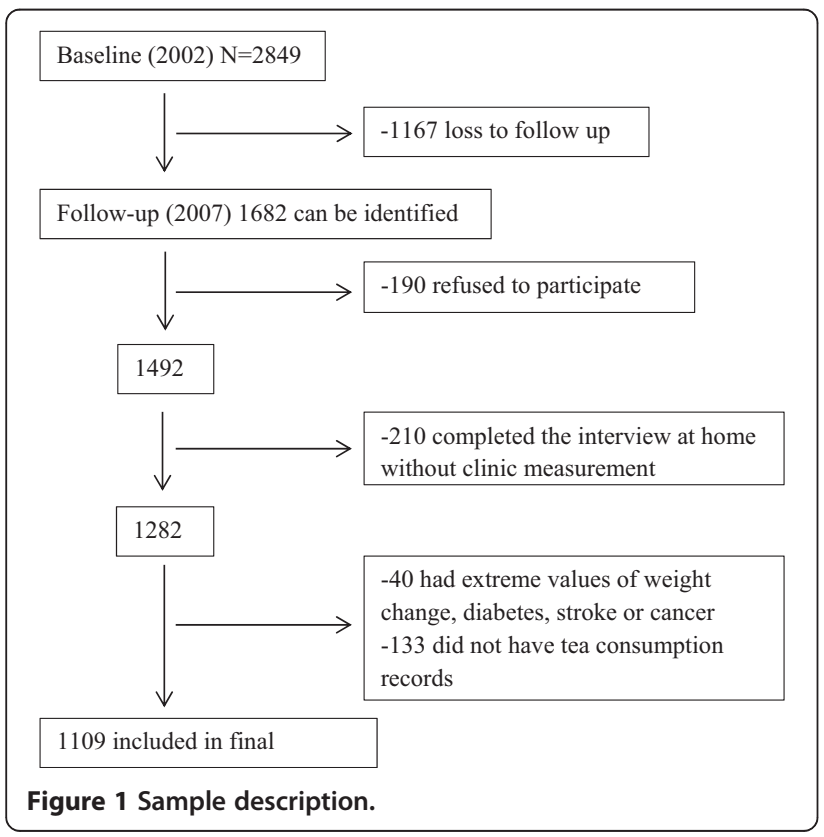

Declaration of Helsinki and the Jiangsu Provincial Centre for Disease Control and Prevention approved all procedures. Written informed consent was obtained from all participants.

\section{Data collection and measurements}

Participants were interviewed at their homes by trained health workers using a standard questionnaire [29].

\section{Exposure variables-tea consumption in 2007}

The usual weekly green tea and black tea consumption was assessed by the question "How much tea do you drink each week? 1) green tea_liang 2) black tea_ liang". "Lang" is a Chinese unit corresponding to $50 \mathrm{~g}$. Total tea consumption was the sum of green and black tea in grams per day.

Outcome variables-change in BP between 2007 and 2002

After 5 minutes seated, BP was measured twice by mercury sphygmomanometer on the right upper arm at both baseline and follow-up. The mean of the two measurements was used in the analyses. The cuff size was selected on the basis of the upper arm circumference to ensure that the cuff did not overlap [2]. Hypertension was defined as SBP above $140 \mathrm{mmHg}$ and/or DBP above $90 \mathrm{mmHg}$, or use of antihypertensive medications.

\section{Dietary intake}

In 2002, dietary intake patterns during the previous year were determined by a series of detailed questions about the usual frequency and quantity of intake of 33 food groups and beverages. The food frequency questionnaire (FFQ) has been validated [32,33] and reported to be a useful method for the collection of individual food consumption information in face-to-face interviews, but not in self-administered surveys due to the current level of education of the majority of the Chinese population. We assessed the intake of specific nutrients using a 3-day weighed food diary, which recorded all foods consumed by each individual on three consecutive days including the weekend. We did not consider under- and overreporting of energy intake to be an issue because upon reviewing the food diaries with the participants the health workers would clarify any intake value for particular foods that fell below or above the usual value reportedly consumed by the population within the region. Food consumption data were analysed using the Chinese Food Composition Table [34].

\section{Other lifestyle factors}

These were assessed in both 2002 and 2007 by questionnaire which asked about cigarette smoking current, past smoking and passive; eating out frequently (coded as yes or no); the frequency and amount of alcohol consumed. 
Table 1 Sample characteristic (in 2002) according to tea consumption (in 2007) among Chinese adults ${ }^{\mathrm{a}}(\mathrm{N}=1109$ )

\begin{tabular}{|c|c|c|c|c|c|c|c|c|c|c|c|c|}
\hline & \multicolumn{4}{|c|}{ Total tea } & \multicolumn{4}{|c|}{ Green tea } & \multicolumn{4}{|c|}{ Black tea } \\
\hline & $\begin{array}{c}0 \mathrm{~g} / \text { day } \\
(\mathrm{N}=846)\end{array}$ & $\begin{array}{c}<10 \text { g/day } \\
\left(7.1 \mathrm{~g} / \text { day }^{\mathrm{b}},\right. \\
\mathrm{N}=148)\end{array}$ & $\begin{array}{c}>10 \mathrm{~g} / \text { day } \\
(14.3 \mathrm{~g} / \mathrm{day}, \\
\mathrm{N}=115)\end{array}$ & $P$ & $\begin{array}{c}0 \mathrm{~g} / \mathrm{day} \\
(\mathrm{N}=900)\end{array}$ & $\begin{array}{c}<10 \text { g/day } \\
(7.1 \text { g/day, } \\
N=139)\end{array}$ & $\begin{array}{c}>10 \text { g/day } \\
(14.3 \mathrm{~g} / \text { day, } \\
\mathrm{N}=70)\end{array}$ & $P$ & $\begin{array}{c}0 \mathrm{~g} / \mathrm{day} \\
(\mathrm{N}=1018)\end{array}$ & $\begin{array}{c}<10 \text { g/day } \\
(7.1 \text { g/day, } \\
N=51)\end{array}$ & $\begin{array}{c}>10 \mathrm{~g} / \mathrm{day} \\
(14.3 \mathrm{~g} / \mathrm{day}, \\
\mathrm{N}=40)\end{array}$ & $P$ \\
\hline Age & 48.9 & 50.2 & 50.0 & 0.37 & 48.9 & 50.8 & 49.7 & 0.11 & 49.1 & 50.4 & 49.8 & 0.74 \\
\hline (years) & $(0.5)$ & (1.1) & (1.1) & & $(0.4)$ & (1.1) & (1.4) & & $(0.4)$ & (1.8) & (2.1) & \\
\hline Men (\%) & 32.86 & 69.59 & 79.13 & $<0.01$ & 35.2 & 71.2 & 80.0 & $<0.01$ & 39.8 & 68.6 & 80.0 & $<0.01$ \\
\hline Urban (\%) & 11.8 & 13.5 & 17.4 & 0.23 & 11.3 & 18.7 & 17.1 & 0.03 & 12.77 & 15.69 & 5.00 & 0.28 \\
\hline Low education (\%) & 55.2 & 50.7 & 43.5 & 0.01 & 55.0 & 48.9 & 41.4 & $<0.01$ & 53.9 & 49.0 & 45.0 & 0.16 \\
\hline Manual job (\%) & 55.6 & 45.9 & 40.0 & $<0.01$ & 54.8 & 43.2 & 44.3 & 0.01 & 53.6 & 47.1 & 35.0 & 0.05 \\
\hline No active commuting (\%) & 39.5 & 43.9 & 45.2 & 0.06 & 40.2 & 43.9 & 40.0 & 0.06 & 40.1 & 43.1 & 52.5 & 0.58 \\
\hline No leisure time physical activity (\%) & 92.8 & 87.8 & 85.2 & 0.03 & 92.7 & 85.6 & 85.7 & 0.03 & 91.9 & 84.3 & 87.5 & 0.03 \\
\hline Sleeping $<7$ h/day & 11.8 & 12.4 & 15.9 & $<0.01$ & 12.2 & 11.8 & 14.7 & 0.02 & 12.0 & 13.7 & 17.5 & 0.09 \\
\hline Sedentary activity $<1 \mathrm{~h} /$ day & 18.8 & 6.8 & 5.2 & $<0.01$ & 18.2 & 6.5 & 2.9 & $<0.01$ & 16.5 & 3.9 & 12.5 & $<0.01$ \\
\hline Smoker (\%) & 19.9 & 51.4 & 58.3 & $<0.01$ & 22.1 & 48.9 & 62.9 & $<0.01$ & 25.7 & 51.0 & 57.5 & $<0.01$ \\
\hline Alcohol drinker (\%) & 20.9 & 40.8 & 40.9 & $<0.01$ & 22.7 & 36.2 & 42.9 & $<0.01$ & 24.4 & 37.3 & 42.5 & $<0.01$ \\
\hline Weight & 59.6 & 60.6 & 60.7 & 0.37 & 59.5 & 61.4 & $61.5 \quad(1.2)$ & 0.04 & 59.97 & 58.53 & 58.48 & 0.38 \\
\hline$(\mathrm{kg})^{\mathrm{c}}$ & $(0.3)$ & $(0.9)$ & $(0.9)$ & & $(0.3)$ & $(0.8)$ & & & $(0.3)$ & (1.3) & (1.5) & \\
\hline Waist circumference & 78.5 & 79.5 & 79.8 & 0.26 & 78.4 & 80.3 & 80.3 & 0.05 & 78.86 & 77.59 & 78.24 & 0.60 \\
\hline$(\mathrm{cm})^{c}$ & $(0.3)$ & $(0.8)$ & $(0.9)$ & & $(0.3)$ & $(0.8)$ & (1.1) & & (0.3) & (1.3) & (1.5) & \\
\hline Central obesity (\%) & 31.7 & 27.7 & 22.6 & 0.10 & 30.6 & 30.2 & 25.7 & 0.69 & 31.5 & 17.7 & 15.0 & 0.01 \\
\hline Obesity (\%) (BMI $\left.\geq 28 \mathrm{~kg} / \mathrm{m}^{2}\right)$ & 10.3 & 8.1 & 7.8 & 0.43 & 10.0 & 7.9 & 10.0 & 0.21 & 10.3 & 2.0 & 5.0 & 0.21 \\
\hline BMI & 23.3 & 23.7 & 23.8 & 0.30 & 23.3 & 24.0 & 24.0 & 0.04 & 23.4 & 22.8 & 23.4 & 0.36 \\
\hline$\left(\mathrm{kg} / \mathrm{m}^{2}\right)^{\mathrm{c}}$ & $(0.1)$ & (0.3) & $(0.3)$ & & $(0.1)$ & (0.3) & (0.4) & & $(0.1)$ & $(0.5)$ & (0.5) & \\
\hline Hypertension (\%) & 29.7 & 37.8 & 33.9 & 0.11 & 29.7 & 37.4 & 38.6 & 0.07 & 31.3 & 37.3 & 20.0 & 0.20 \\
\hline SBP & 126.7 & 126.5 & 126.2 & 0.97 & 126.5 & 127.0 & 127.2 & 0.93 & 126.8 & 125.6 & 122.0 & 0.28 \\
\hline$(\mathrm{mmHg})^{c}$ & $(0.7)$ & (1.6) & (1.8) & & (0.6) & (1.6) & (2.3) & & (0.6) & (2.7) & (3.0) & \\
\hline DBP & 79.6 & 80.3 & 81.0 & 0.47 & 79.5 & 80.9 & 82.5 & 0.06 & 80.0 & 81.2 & 75.6 & 0.04 \\
\hline$(\mathrm{mmHg})^{c}$ & $(0.4)$ & $(0.9)$ & (1.1) & & $(0.4)$ & (1.0) & (1.4) & & $(0.4)$ & (1.6) & (1.8) & \\
\hline Energy & 2376.5 & 2260.8 & 2288.2 & 0.07 & 2363.5 & 2286.3 & 2333.5 & 0.40 & 2361.6 & 2222.9 & 2272.3 & 0.21 \\
\hline$(\text { Kcal/day })^{c}$ & (21.4) & (51.6) & $(58.8)$ & & (20.6) & $(53.3)$ & $(74.6)$ & & $(19.2)$ & $(86.2)$ & $(97.7)$ & \\
\hline Fat & 80.1 & 87.5 & 87.4 & $<0.01$ & 80.8 & 86.5 & 86.2 & 0.02 & 81.0 & 95.1 & 84.6 & $<0.01$ \\
\hline$(g / \text { day })^{d}$ & (0.9) & (2.1) & (2.4) & & $(0.8)$ & (2.2) & (3.1) & & (0.8) & (3.5) & (4.0) & \\
\hline
\end{tabular}


Table 1 Sample characteristic (in 2002) according to tea consumption (in 2007) among Chinese adults ${ }^{\mathrm{a}}(\mathrm{N}=1109)$ (Continued)

\begin{tabular}{|c|c|c|c|c|c|c|c|c|c|c|c|c|}
\hline Protein & 72.0 & 72.4 & 76.9 & $<0.01$ & 72.1 & 74.0 & 75.6 & 0.09 & 72.3 & 71.8 & 79.9 & $<0.0$ \\
\hline$(g / \text { day })^{d}$ & $(0.5)$ & $(1.2)$ & $(1.4)$ & & $(0.5)$ & $(1.2)$ & (1.7) & & $(0.4)$ & $(2.0)$ & $(2.3)$ & \\
\hline Carbohydrate & 324.6 & 307.2 & 306.0 & $<0.01$ & 321.8 & 314.8 & 312.3 & 0.27 & $322.9(1.9)$ & 283.4 & 302.4 & $<0.0$ \\
\hline$(g / \text { day })^{d}$ & $(2.1)$ & $(5.2)$ & $(5.9)$ & & $(2.1)$ & $(5.4)$ & (7.5) & & & $(8.6)$ & $(9.7)$ & \\
\hline Fibre & 12.6 & 9.6 & 9.5 & $<0.01$ & 12.5 & 9.8 & (1.1) & $<0.01$ & 12.0 & 10.5 & 10.5 & 0.30 \\
\hline$(g / d a y)^{d}$ & $(0.3)$ & $(0.7)$ & $(0.8)$ & & $(0.3)$ & $(0.8)$ & & & (0.3) & $(1.3)$ & $(1.4)$ & \\
\hline Sodium & 6.7 & 6.9 & 6.8 & 0.89 & 6.8 & 6.7 & 6.8 & 0.99 & 6.7 & 7.3 & 6.8 & 0.66 \\
\hline$(g / \text { day })^{d}$ & $(0.1)$ & $(0.4)$ & $(0.4)$ & & $(0.1)$ & $(0.4)$ & $(0.5)$ & & $(0.1)$ & $(0.6)$ & $(0.7)$ & \\
\hline
\end{tabular}

${ }^{a}$ Mean(SE), nutrients and alcohol intake were calculated from weighted food records, other food intakes were calculated from food frequency questionnaire.

${ }^{\mathrm{b}}$ Median tea consumption. ${ }^{\mathrm{C}}$ Adjusted for age and sex. ${ }^{\mathrm{d}}$ Adjusted for age and sex and energy intake. ${ }^{\mathrm{B}}$ Based on IDF definition for Chinese population. 
Questions on daily commuting were grouped into three categories: (1) motorized transportation, or $0 \mathrm{~min}$ of walking or cycling; (2) walking or cycling for 1-29 min; (3) walking or cycling for $\geq 30 \mathrm{~min}$. Daily leisure time physical activity was grouped into three categories: $0,1-$ 29 and $\geq 30 \mathrm{~min}$. Daily sleeping was grouped into three categories: $<7,7-8$ and $\geq 9$ hours. Daily time spent on sedentary activities (viewing television, operating a computer, playing video games and reading during leisure time) was classified into four categories: $<1,1-1.9,2-2.9$ and $\geq 3$ hours. Education was recoded into 'Low' (illiteracy, primary school), 'Medium' (junior middle school) or 'High' (high middle school or higher), based on six categories of education levels in the questionnaire. Occupation was recoded into 'Manual' or 'Non-manual' based on a question with twelve occupational categories.

\section{Anthropometric measurements}

In both 2002 and 2007, anthropometric measurements were obtained using standard protocols and techniques. Body weight was measured in light indoor clothing without shoes to the nearest $100 \mathrm{~g}$. Height was measured without shoes to the nearest millimetre using a stadiometer. Waist circumference was measured to the nearest millimetre midway between the inferior margin of the last rib and the crest of the ilium, in the mid-axillary line in a horizontal plane. Family history of hypertension was defined as the presence of known family members

Table 2 Linear regression $\beta$ coefficients (95\% confidence interval) for categories of total tea, green tea and black tea consumption predicting 5-year change in blood pressure in 1109 adults participating in the Jiangsu Nutrition Study

\begin{tabular}{|c|c|c|c|}
\hline & $<10 \mathrm{~g} /$ day $^{\mathrm{a}}(7.1 \mathrm{~g} / \text { day })^{\mathrm{b}}, \beta(95 \% \mathrm{Cl})$ & $>10 \mathrm{~g} /$ day $^{\mathrm{a}}$ (14.3 g/day), $\beta(95 \% \mathrm{Cl})$ & $\mathrm{P}$ for trend \\
\hline \multicolumn{4}{|l|}{ Total tea } \\
\hline \multicolumn{4}{|l|}{ SBP } \\
\hline Model 1 & $-1.10(-4.56$ to 2.36$)$ & $-2.41(-6.30$ to 1.48$)$ & 0.20 \\
\hline Model 2 & $-0.29(-3.78$ to 3.20$)$ & $-2.03(-5.97$ to 1.91$)$ & 0.35 \\
\hline Model 3 & $0.31(-3.45$ to 3.51$)$ & $-1.76(-5.70$ to 2.19$)$ & 0.45 \\
\hline \multicolumn{4}{|l|}{ DBP } \\
\hline Model 1 & $-1.92(-3.93$ to 0.09$)$ & $-2.79(-5.05$ to -0.53$)$ & $<0.01$ \\
\hline Model 2 & $-1.44(-3.47$ to 0.60$)$ & $-2.64(-4.94$ to -0.34$)$ & 0.02 \\
\hline Model 3 & $-1.30(-3.33$ to 0.73$)$ & $-2.41(-4.71$ to -0.11$)$ & 0.028 \\
\hline \multicolumn{4}{|l|}{ Green tea } \\
\hline \multicolumn{4}{|l|}{ SBP } \\
\hline Model 1 & $-1.17(-4.69$ to 2.35$)$ & $-3.96(-8.73$ to 0.81$)$ & 0.10 \\
\hline Model 2 & $-0.45(-4.01$ to 3.11$)$ & $-3.28(-8.08$ to 1.52$)$ & 0.23 \\
\hline Model 3 & $-0.14(-3.40$ to 3.77$)$ & $-2.71(-7.50$ to 2.08$)$ & 0.35 \\
\hline \multicolumn{4}{|l|}{ DBP } \\
\hline Model 1 & $-2.37(-4.41$ to -0.33$)$ & $-4.25(-7.02$ to -1.49$)$ & $<0.01$ \\
\hline Model 2 & $-1.87(-3.94$ to 0.21$)$ & $-3.96(-6.76$ to -1.16$)$ & $<0.01$ \\
\hline Model 3 & $-1.67(-3.74$ to 0.40$)$ & $-3.68(-6.47$ to -0.89$)$ & $<0.01$ \\
\hline \multicolumn{4}{|l|}{ Black tea } \\
\hline \multicolumn{4}{|l|}{ SBP } \\
\hline Model 1 & $-2.99(-8.41$ to 2.44$)$ & $2.41(-3.70$ to 8.51$)$ & 0.85 \\
\hline Model 2 & $-2.34(-7.79$ to 3.10$)$ & $1.82(-4.26$ to 7.90$)$ & 0.89 \\
\hline Model 3 & $-2.46(-7.90$ to 2.98$)$ & $1.40(-4.66$ to 7.46$)$ & 0.99 \\
\hline \multicolumn{4}{|l|}{ DBP } \\
\hline Model 1 & $-3.42(-6.56$ to -0.27$)$ & $3.69(0.15$ to 7.24$)$ & 0.43 \\
\hline Model 2 & $-2.82(-5.99$ to 0.35$)$ & $3.18(-0.37$ to 6.72$)$ & 0.46 \\
\hline Model 3 & $-2.71(-5.88$ to 0.46$)$ & $2.99(-0.54$ to 6.52$)$ & 0.49 \\
\hline
\end{tabular}



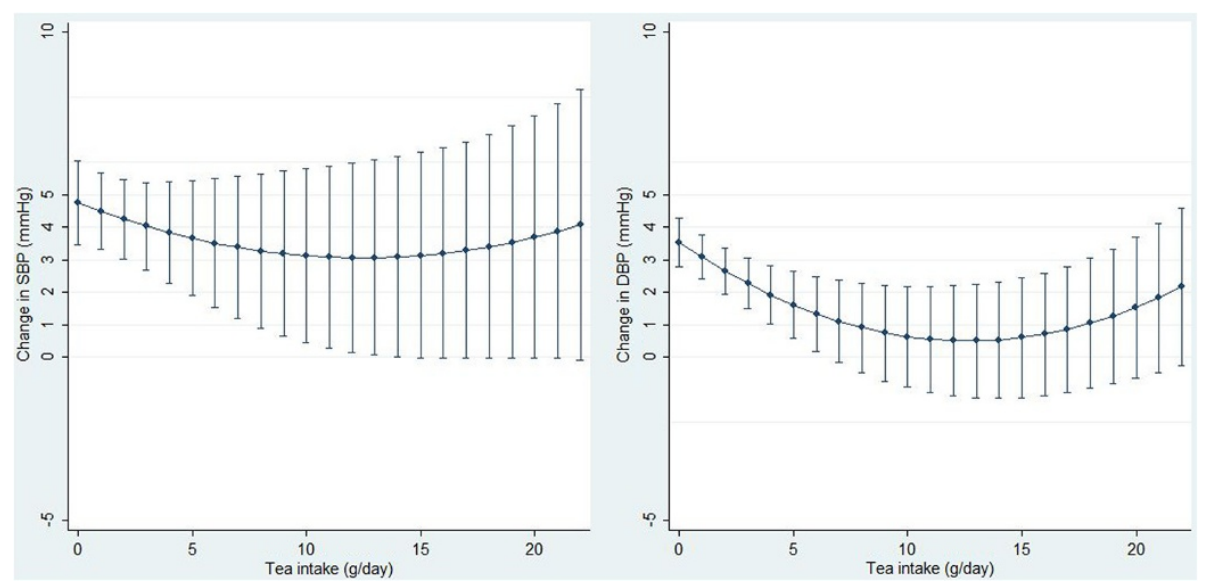

Figure 2 Predicted association between tea consumption and blood pressure changes over $\mathbf{5}$ years among Chinese adults ${ }^{\mathrm{a}}$. Command marginsplot was used to generate the graph. Tea intake was treated as continuous variables. 11 participants with tea consumption more than $22 \mathrm{~g} /$ day were excluded. ${ }^{\text {Madels }}$ adjusted for variables in model 3 of Table 2.

with hypertension in any of three generations (siblings, parents, or grandparents).

\section{Statistics}

Total tea, green tea and black tea consumption were recoded into three categories: $0, \leq 10,>10$ g/day. The $\chi^{2}-$ test was used to compare differences between categorical variables and ANOVA was used to compare differences in continuous variables between groups. Mixed-effects linear regression was used to determine the association between different types of tea consumption and BP change. In the full model we adjusted for age, sex, education, occupation, active commuting, leisure time physical activity, sedentary activity, smoking, passive smoking, alcohol drinking, overweight (yes/no) at the baseline, change in BMI, central obesity (yes/no), eating out, family history of hypertension, hypertension medication, energy, sodium, fibre, potassium, fat, fruit, vegetable and salt intake. These multivariable models were adjusted for household cluster, incorporated as random effects in these models. We tested for linear trends across the categories of tea consumed by assigning each participant the median value of the category and modelling this value as a continuous variable. After adjusting for the covariates described in the full model above, we graphically examined the relationship between tea consumption (continuous, g/day) and BP change. Both linear and quadratic terms of tea consumption were put in the model to allow for nonlinear associations. All the analyses were performed using STATA 12 (Stata Corporation, College Station, Texas, USA). A two-sided $\mathrm{P}$ value less than 0.05 was considered to be statistically significant.

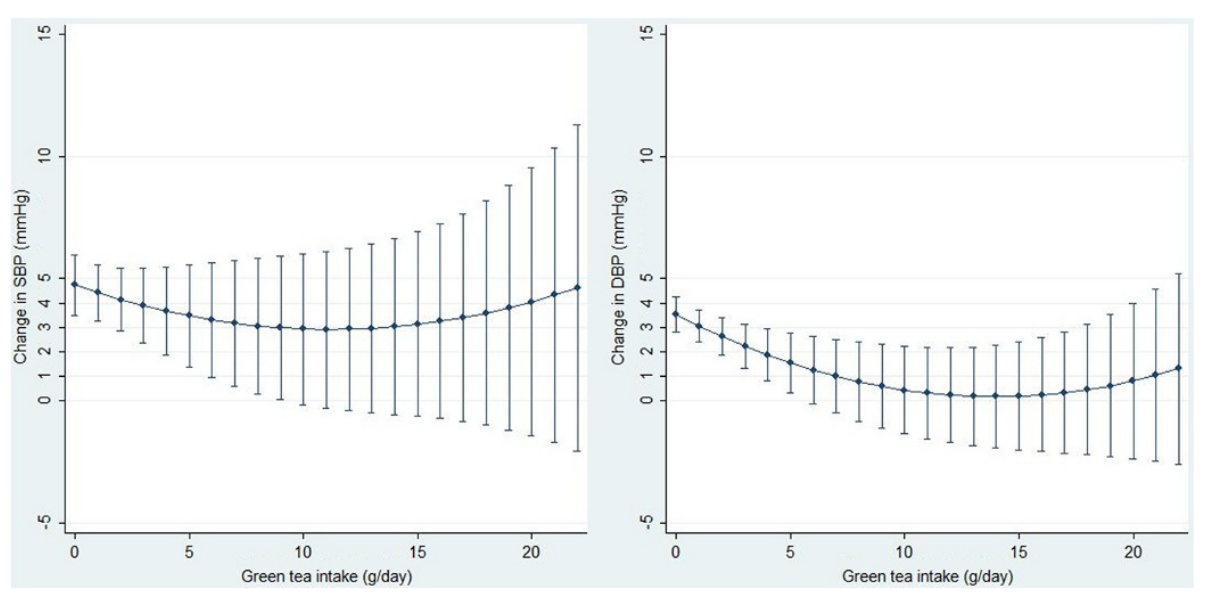

Figure 3 Predicted association between green tea consumption and blood pressure changes over 5 years among Chinese adults ${ }^{\mathrm{a}}$. Command marginsplot was used to generate the graph. Green tea intake was treated as continuous variables. 11 participants with tea consumption more than $22 \mathrm{~g} /$ day were excluded. ${ }^{a}$ Models adjusted for variables in model 3 of Table 2. 
Table 3 Stratified regression coefficients ( $95 \%$ confidence interval) for SBP change according to the total tea, green tea and black tea consumption categories ( $\beta$ coefficients and $95 \%$ confidence intervals) among Chinese adults $(n=1109)^{a}$

\begin{tabular}{cccc}
\hline & \multicolumn{2}{c}{ Categories of tea consumption } & \\
\hline $\mathrm{N}$ & $<10 \mathrm{~g} /$ day $^{\mathrm{b}}$ & $>10 \mathrm{~g} /$ day $^{\mathrm{b}}$ & P for trend \\
& $\left(7.1 \mathrm{~g} /\right.$ day $^{\mathrm{c}}$ & $(14.3 \mathrm{~g} /$ day $)$ & interaction \\
\hline
\end{tabular}

Total tea

Central obesity

$\begin{array}{lll}\text { Yes } & 334 & 0.20(-7.17 \text { to } 7.57) \\ \text { No } & 768 & -0.35(-4.18 \text { to } 3.47)\end{array}$

BMI

$>24 \mathrm{~kg} / \mathrm{m}^{2} \quad 443 \quad 0.56(-5.41$ to 6.52$)$

$<24 \mathrm{~kg} / \mathrm{m}^{2} \quad 659 \quad 0.19(-3.92$ to 4.29$)$

Sex

$\begin{array}{rcc}\text { Male } & 469 & -0.24(-4.55 \text { to } 4.06) \\ \text { Female } & 633 & 1.22(-4.67 \text { to } 7.1)\end{array}$

$0.68(-8.51$ to 9.87$)$
$-2.81(-7.04$ to 1.43$)$

Smoking

$\begin{array}{lll}\text { Yes } & 310 & 0.54(-4.41 \text { to } 5.48) \\ \text { No } & 792 & 0.66(-4.11 \text { to } 5.43)\end{array}$

0.97(-4.14 to 6.07)

Drinking

$\begin{array}{lll}\text { Yes } & 281 & 0.91(-4.81 \text { to } 6.63) \\ \text { No } & 805 & 1.19(-3.41 \text { to } 5.78)\end{array}$

Green tea

$-3.51(-8.66$ to 1.64$)$

Central obesity

$\begin{array}{ll}\text { Yes } & 334 \\ \text { No } & 768\end{array}$

$$
0.69(-6.47 \text { to } 7.85)
$$

$1.39(-9.59$ to 12.37$)$

$\mathrm{BMI}$

$>24 \mathrm{~kg} / \mathrm{m}^{2}$

$<24 \mathrm{~kg} / \mathrm{m}^{2}$

443

659

Sex

$$
\text { Male }
$$

Female

Smoking

$\begin{array}{ll}\text { Yes } & 310 \\ \text { No } & 792\end{array}$

$$
792
$$

Drinking

$\begin{array}{lll}\text { Yes } & 281 & -1.06(-7.07 \text { to } 4.95) \\ \text { No } & 805 & 1.09(-3.47 \text { to } 5.66)\end{array}$

$1.19(-3.76$ to 6.13$)$

$-0.5(-5.35$ to 4.35$)$

$-0.03(-5.95$ to 5.89$)$

$1.03(-3.28$ to 5.34$)$

0.37(-7.75 to 8.50$)$

$-4.13(-9.97$ to 1.70$)$

$-2.83(-8.11$ to 2.45$)$

$-1.84(-12.37$ to 8.68$)$

$-10.06(-17.75$ to -2.36$)$

$-3.06(-10.23$ to 4.12$)$

0.07

0.95

Black tea

Central obesity

$\begin{array}{ll}\text { Yes } & 334 \\ \text { No } & 768\end{array}$

$$
\begin{aligned}
& -11.39(-25.64 \text { to } 2.87) \\
& -0.23(-5.85 \text { to } 5.39)
\end{aligned}
$$
6.25(-11.07 to 23.58)
$1.06(-5.14$ to 7.26$)$

BMI

$$
\begin{aligned}
& >24 \mathrm{~kg} / \mathrm{m}^{2} \\
& <24 \mathrm{~kg} / \mathrm{m}^{2}
\end{aligned}
$$$$
443
$$

659
$-0.93(-11.69$ to 9.83$)$
$-2.04(-7.95$ to 3.87$)$

$0.43(-5.33$ to 6.2$)$

$-4.7(-11.1$ to 1.7$)$

0.37

0.34

0.92

0.78

0.038
0.93

0.80

0.76

$1.75(-9.06$ to 12.56$)$

0.83

$1.55(-5.51$ to 8.6$)$
0.52

0.90

0.052 
Table 3 Stratified regression coefficients (95\% confidence interval) for SBP change according to the total tea, green tea and black tea consumption categories ( $\beta$ coefficients and $95 \%$ confidence intervals) among Chinese adults $(n=1109)^{a}$ (Continued)

\begin{tabular}{|c|c|c|c|c|c|}
\hline \multicolumn{6}{|l|}{ Sex } \\
\hline Male & 469 & $-2.92(-9.22$ to 3.39$)$ & $1.63(-5.01$ to 8.27$)$ & 0.95 & 0.15 \\
\hline Female & 633 & $2.72(-7.23$ to 12.67$)$ & $8.01(-5.32$ to 21.34$)$ & 0.21 & \\
\hline \multicolumn{6}{|l|}{ Smoking } \\
\hline Yes & 310 & $-3.88(-10.87$ to 3.11$)$ & $2.49(-4.9$ to 9.88$)$ & 0.88 & 0.39 \\
\hline No & 792 & $0.42(-7.48$ to 8.32$)$ & $2.25(-7.17$ to 11.66$)$ & 0.65 & \\
\hline \multicolumn{6}{|l|}{ Drinking } \\
\hline Yes & 281 & $3.76(-4.98$ to 12.49$)$ & $3.43(-5.98$ to 12.85$)$ & 0.33 & 0.67 \\
\hline No & 805 & $-3.93(-11.24$ to 3.39$)$ & $0.43(-7.5$ to 8.36$)$ & 0.72 & \\
\hline
\end{tabular}

$\mathrm{Cl}$, confidence interval. ${ }^{\mathrm{a}}$ Models adjusted for variables in model3 of Table 2 . Stratifying variables are not adjusted for in corresponding models. ${ }^{\mathrm{b}}$ Referent category is non-tea drinkers. ${ }^{\mathrm{C}}$ Median tea consumption.

\section{Results}

The mean total tea, green tea and black tea consumption in the sample were $2.80 \mathrm{~g} /$ day, $1.88 \mathrm{~g} /$ day and $0.92 \mathrm{~g} /$ day. Of the 1109 participants, 846 reported no tea drinking. Table 1 shows the association between tea consumption and intake of nutrients and specific food items or food groups. Tea consumption was positively associated with fat and protein but inversely associated with carbohydrate and fibre intake. There were no significant differences in energy, sodium, potassium or salt intake across the tea consumption categories. Rice and vegetable intake was higher among individuals with high tea consumption as compared with those who did not drink tea. In contrast, wheat flour intake was significantly lower among those with the higher levels of tea consumption than those with no tea consumption. The prevalence of smoking and alcohol consumption increased with the increase of tea consumption (all $\mathrm{p}<0.05)$. There was a positive association between tea consumption and socio-economic status (i.e. education, occupation), and physical activity. There was a negative association between tea consumption and sleep. There were no significant differences in SBP and DBP across tea consumption categories. There were no significant differences in cigarette smoking and alcohol consumption between the baseline and five-year follow-up time points (Additional file 1: Table S2). Seventy participants $(6.3 \%)$ reported taking hypertension medication (at both baseline and follow-up). On average SBP increased by $4.5 \mathrm{mmHg}$ (SD 19.1) and DBP increased by $3.0 \mathrm{mmHg}$ (SD 11.2) over 5 years. The prevalence of hypertension at follow-up across total tea consumption categories of none, $<10 \mathrm{~g} /$ day and $\geq 10 \mathrm{~g} /$ day was $41.8 \%, 43.9 \%$ and $41.7 \%$ respectively.

Table 2 shows the association between tea consumption and BP changes in multivariable regression analyses. There was an inverse association between total tea/green tea consumption and changes in DBP. In the fully adjusted model (model 3), including dietary and non- dietary covariates, the $\beta$ values and $95 \%$ confidence intervals for DBP changes were $0,-1.30(-3.33$ to 0.73$)$ and $-2.41(-4.71$ to -0.11 ) ( $\mathrm{p}$ for trend $=0.028$ ) for total tea consumption of $0,1-10 \mathrm{~g} /$ day, and $>10 \mathrm{~g} /$ day; $0,-1.67$ $(-3.74$ to 0.40$),-3.68(-6.47$ to -0.89$)(\mathrm{p}<0.01)$ for green tea consumption of $0,1-10 \mathrm{~g} /$ day, and $>10 \mathrm{~g} /$ day.

Figures 2 and 3 show the association between total tea/green tea consumption (as continuous variables) and BP changes with adjustment for all covariates. There was a dose-response relationship between total tea/green tea consumption and DBP change but not SBP change. The confidence intervals were wider at the right end due to the small number of participants with high tea consumption.

There were no significant interactions for tea consumption with central obesity, BMI, sex, smoking and drinking in relation to SBP change. However, high consumption of green tea was significantly inversely associated with SBP change among those who were non-obese and non-smokers (Table 3).

An inverse association between total /green tea consumption and DBP change was observed only among non-smokers. However, no association was found between black tea consumption and DBP change in any subgroup (Table 4).

\section{Discussion}

In this population study, we found an inverse association between green but not black tea consumption and 5year change in both SBP and DBP. The beneficial effect of high green tea consumption on both SBP and DBP occurred only in non-smokers and in the case of SBP only in those without abdominal obesity. There was a clear dose-response relationship between green tea consumption and DBP change.

The inverse association between tea consumption and BP change in our study was limited to green tea consumption. A recent randomized trial which included 95 
Table 4 Stratified regression coefficients (95\% confidence interval) for DBP change according to the total tea, green tea and black tea consumption categories ( $\beta$ coefficients and $95 \%$ confidence intervals) among Chinese adults $(n=1109)^{a}$

\begin{tabular}{cccc}
\hline \multicolumn{4}{c}{ Categories of tea consumption } \\
\hline $\mathrm{N}$ & $<10 \mathrm{~g} /$ day $^{\mathrm{b}}$ & $>10 \mathrm{~g} /$ day $^{\mathrm{b}}$ & $P$ for trend \\
& $\left(7.1 \mathrm{~g} /\right.$ day $^{\mathrm{c}}$ & $(14.3 \mathrm{~g} /$ day $)$ & interaction \\
\hline
\end{tabular}

Total tea

Central obesity

\section{Yes}

768

$0.55(-3.55$ to 4.65$)$

$-1.72(-4.03$ to 0.60$)$

$-2.94(-5.50$ to -0.37$)$

BMI

$$
>24 \mathrm{~kg} / \mathrm{m}^{2}
$$

\section{3}

$-1.24(-4.57$ to 2.08$)$

$<24 \mathrm{~kg} / \mathrm{m}^{2}$

659

$-0.93(-3.43$ to 1.57$)$

Sex

$$
\text { Male }
$$

469

Female

$$
633
$$

Smoking

$$
\text { Yes }
$$

310

792

Drinking

$$
\text { No }
$$$$
792
$$

$-1.92(-4.58$ to 0.74$)$

$0.06(-3.28$ to 3.4$)$

$0.76(-2.43$ to 3.94$)$

$-2.43(-5.15$ to 0.29$)$

805

$0.61(-2.88$ to 4.1$)$

$-1.25(-3.86$ to 1.35$)$

Green tea

Central obesity

$\begin{array}{ll}\text { Yes } & 334 \\ \text { No } & 768\end{array}$

BMI

$>24 \mathrm{~kg} / \mathrm{m}^{2}$

$<24 \mathrm{~kg} / \mathrm{m}^{2}$

Sex

$$
\text { Male }
$$

Female

Smoking

$\begin{array}{ll}\text { Yes } & 310 \\ \text { No } & 792\end{array}$

443

659

469

633

Drinking

$\begin{array}{ll}\text { Yes } & 281 \\ \text { No } & 805\end{array}$

805

Black tea

Central obesity

$\begin{array}{ll}\text { Yes } & 334 \\ \text { No } & 768\end{array}$

BMI

$$
>24 \mathrm{~kg} / \mathrm{m}^{2}
$$

$<24 \mathrm{~kg} / \mathrm{m}^{2}$

659
$0.03(-5.08$ to 5.13$)$

0.91

0.02

0.32

0.64

0.56

0.03

0.52

0.09

0.64
7.35(-2.22 to 16.93$)$

0.78

0.48

$2.44(-1.32$ to 6.2$)$

$-1.73(-7.76$ to 4.3$)$

0.41

0.20

$5.01(0.73$ to 9.29$)$
0.91

$-2.56(-6.15$ to 1.02$)$ 
Table 4 Stratified regression coefficients (95\% confidence interval) for DBP change according to the total tea, green tea and black tea consumption categories ( $\beta$ coefficients and $95 \%$ confidence intervals) among Chinese adults $(n=1109)^{a}$ (Continued)

\begin{tabular}{|c|c|c|c|c|c|}
\hline \multicolumn{6}{|l|}{ Sex } \\
\hline Male & 469 & $-2.68(-6.58$ to 1.22$)$ & $2.45(-1.66$ to 6.56$)$ & 0.62 & 0.32 \\
\hline Female & 633 & $-1.02(-6.66$ to 4.61$)$ & $7.25(-0.3$ to 14.81$)$ & 0.17 & \\
\hline \multicolumn{6}{|l|}{ Smoking } \\
\hline Yes & 310 & $-2.61(-7.1$ to 1.89$)$ & $3.31(-1.44$ to 8.06$)$ & 0.46 & 0.95 \\
\hline No & 792 & $-1.85(-6.36$ to 2.65$)$ & $2.49(-2.88$ to 7.86$)$ & 0.70 & \\
\hline \multicolumn{6}{|l|}{ Drinking } \\
\hline Yes & 281 & $1.75(-3.56$ to 7.05$)$ & $5.01(-0.85$ to 10.87$)$ & 0.09 & 0.41 \\
\hline No & 805 & $-3.57(-7.72$ to 0.57$)$ & $2.52(-1.98$ to 7.02$)$ & 0.83 & \\
\hline
\end{tabular}

$\mathrm{Cl}$, confidence interval. ${ }^{\mathrm{a}}$ Models adjusted for variables in model3 of Table 2 . Stratifying variables are not adjusted for in corresponding models. ${ }^{\mathrm{b}}$ Referent category is non-tea drinkers. ${ }^{\mathrm{C}}$ Median tea consumption.

participants showed that consumption of black tea lowers BP in individuals with normal to high-normal range BPs [23]. We did not find any association between black tea and BP change in our study, possibly because relatively few participants consumed black tea.

There are relatively few epidemiological studies that examine the relationship between tea consumption and blood pressure $[13,18,19,35]$. The majority of these showed a protective effect of tea on BP $[13,18,19]$. In a crosssectional study in Taiwan, Yang et al. found that habitual tea consumption, defined as daily consumption of moderate strength green tea or oolong tea of $120 \mathrm{~mL} /$ day or more for 1 year significantly lowers the risk of hypertension [18]. Another cross-sectional study in Western Australia undertaken by Hodgson et al. showed that green tea and black tea intake were associated with significantly lower SBP and DBP in older women: consuming 1 cup (250 ml) green/black tea per day was associated with a $2.2 \mathrm{~mm} \mathrm{Hg}$ lower SBP and a $0.9 \mathrm{~mm} \mathrm{Hg}$ lower in DBP [19]. In Norway, Stensvold et al. found that SBP decreased with increasing black tea consumption: comparing those who drank five or more cups/day of tea with those who drank less than one cup/day, the regression coefficients for SBP were -3.1 and $-4.0 \mathrm{~mm} \mathrm{Hg}$ in SBP in men and women, respectively [13]. There is only one study which found that tea consumption was positively associated with BP [35]. In Algiers, it was found that DBP was higher among tea drinkers than non-drinkers $(78.1 \pm 9.9 \mathrm{~mm} \mathrm{Hg}$ vs $75.2 \pm 9.1 \mathrm{~mm} \mathrm{Hg}$ ). However, the study has a very small sample size of 124 tea drinkers with no adjustment for other dietary factors, and the type of tea consumed was not assessed.

There are a number of potential mechanisms by which tea might lower BP. Tea flavinoids inhibit the activity of angiotensin converting enzyme activity, augment nitric oxide and reduces endothelin-1 concentrations, thereby improving endothelial function and lowering BP [36,37]. Epigallocatechin gallate (EGCG), a tea polyphenol has been shown to improve endothelial function and insulin sensitivity and lower BP in animals [16]. In another animal study, $\gamma$-Aminobutyric acid (GABA) in tea can block nicotine-induced contraction of isolated ileum and prevent the $\mathrm{BP}$ elevation caused by vagal or splanchnic nerve stimulation [21]. Moreover, green tea may induce vascular relaxation in the isolated aortic strips via the blockade of adrenergic $\alpha_{1}$-receptors in rats [38]. Green tea has an anti-inflammatory effect [39]. It is known that inflammation is a risk factor for hypertension [40]. Antioxidants in tea may reduce the vascular sclerosis that occurs with ageing [41]. In addition, one recent meta-analysis has shown moderate consumption of tea substantially enhances endothelial-dependent vasodilation [42].

Dietary patterns that are high in fruit and vegetables and low in sodium are associated with lower blood pressure $[43,44]$. In a group of chimpanzees consuming an optimal vegetable diet, progressive addition of up to $15.0 \mathrm{~g} / \mathrm{d}$ of salt caused large rises in blood pressure, which reversed when the added salt was removed [45]. In the current study, salt intake was not significantly different across the categories of tea consumption, and tea drinking was positively associated with rice and vegetable intake. However, even after adjusting for dietary factors including salt intake, the association between tea consumption and BP change persists. Tea consumption in China increased from 573 million kilogram in 2005 to about 864 million kilogram in 2007, and about $34 \%$ of Chinese drink tea, with $58 \%$ of those consuming green tea $[46,47]$. In addition, salt consumption in China has been decreasing over the past few decades [48]. The increasing prevalence of hypertension therefore prompts questions about the importance of either tea or salt consumption as mitigating factors. Other lifestyles factors, for example obesity, smoking and excess alcohol consumption contribute to hypertension and have been increasing in prevalence in China. A recent study shows that more than $50 \%$ of Chinese men were smokers [49]. 
We observed a beneficial effect of high tea consumption on limiting an increase in DBP only in non-smokers. In addition, an inverse association between tea consumption and DBP change was also found among non-obese and non-alcohol drinkers. In other words, there seems to be no beneficial effects of tea drinking on BP among those with unhealthy lifestyle factors.

The strengths of the study include a large population based sample, and a long time to follow-up (5 years). The data collection and management were undertaken by intensively trained health workers to reduce information bias. We were able to adjust for a range of dietary and non-dietary factors.

The main limitations of the study are that the baseline for tea consumption in 2002 was not collected, and the inability to account for the change in tea consumption during the 5-year follow-up period may affect the BP change. As other lifestyle factors (smoking, alcohol drinking) seemed to be quite stable in the study, we would assume that tea drinking habits were relatively stable also over the five year period. Secondly, there was a relatively high attrition rate of loss to follow-up in the study; this can be attributed to the large number of job migrations from rural areas to urban areas in China [50]. However, there were no differences in energy intake, DBP or gender between those lost to follow-up and those retained, thus limiting bias. Sample power limits the subgroup analyses (e.g. few women drank tea). Finally, although we have adjusted for a few potential covariates, residual confounding may still be present.

\section{Conclusion}

We found that the consumption of total/green tea is inversely associated with 5-year BP change among Chinese adults, an effect abrogated by smoking and obesity.

\section{Additional file}

Additional file 1: Table S1. Sample characteristics between those retained and those lost to follow up. Table S2. Changes in variables abetween baseline and follow-up ( $n=1109)$.

\section{Abbreviations}

BP: Blood pressure; SBP: Systolic blood pressure; DBP: Diastolic blood pressure; JIN: Jiangsu nutrition study; FFQ: Food frequency questionnaire; EGCG: Epigallocatechin gallate; GABA: $\gamma$-Aminobutyric acid.

\section{Competing interests}

The authors declare that they have no competing interests.

\section{Authors' contributions}

$\mathrm{XT}$ analyzed and interpreted the data, and wrote the paper. LG and ZS contributed to assist the analysis. ZS conducted the study. AT, GW and ZS contributed to the writing and editing of the paper. All authors contributed to the final version of the manuscript. All authors read and approved the final manuscript.

\section{Acknowledgments}

The authors thank the participating regional Centers for Disease Control and Prevention in Jiangsu province, including the Nanjing, Xuzhou, Jiangyin, Taicang, Suining, Jurong, Sihong, and Haimen centers for their support for data collection.

\section{Funding sources}

The study is supported by Jiangsu Provincial Natural Science Foundation (BK2008464, PI ZS) and the Jiangsu Provincial Health Bureau, China.

\section{Author details}

'Discipline of Public Health, The University of Adelaide, Adelaide, South Australia, Australia. ${ }^{2}$ Discipline of Medicine, The University of Adelaide, 122 Frome Street, Adelaide, SA 5000, Australia. ${ }^{3}$ Department of Nutrition and Foodborne Disease Prevention, Jiangsu Provincial Centre for Disease Control and Prevention, 172 Jiangsu Road, Nanjing 210009, China.

Received: 23 December 2013 Accepted: 7 October 2014

Published: 14 October 2014

\section{References}

1. Word Health Organisation: World Health Statistics 2012. Geneva: WHO; 2012.

2. Gu D, Reynolds K, Wu X, Chen J, Duan X, Muntner P, Huang G, Reynolds RF, Su S, Whelton PK, He J: Prevalence, awareness, treatment, and control of hypertension in China. Hypertens China 2002, 40:920-927.

3. Li YC, Wang LM, Jiang Y, Li XY, Zhang M, Hu N: Prevalence of hypertension among Chinese adults in 2010. Zhonghua Yu Fang Yi Xue Za Zhi 2012, 46:409-413.

4. MacMahon S, Alderman MH, Lindholm LH, Liu L, Sanchez RA, Seedat YK: Blood-pressure-related disease in a global health priority. Lancet 2008, 371:1480-1482.

5. Lawes CMM, Hoorn SV, Rodgers A: Global burden of blood-pressurerelated disease, 2001. Lancet 2008, 371:1513-1518.

6. Fox K: Hypertension and heart disease. Nurs Stand 1996, 10:52.

7. Lisa JR, Eckstein D, Solomon C: Relationship between arteriosclerosis of the renal artery and hypertension: analysis of 100 necropsies. Am Heart J 1943, 26:714.

8. Rigsby BD: Hypertension improvement through healthy lifestyle modifications. ABNF J 2011, 22:41-43.

9. Appel $L$, Moore TJ, Obarzanek E: A clinical trial of the effects of dietary patterns on blood pressure. N Engl J Med 1997, 336:1117-1124.

10. Sacks FM, Svetkey LP, Vollmer WM: Effects on blood pressure of reduced dietary sodium and the dietary approaches to stop hypertension (DASH) diet. N Engl J Med 2001, 344:3-10.

11. Beilin LJ, Puddey IB, Burke V: Lifestyle and hypertension. Am J Hypertens 1999, 12:934.

12. Taubert D, Roesen R, Schomig E: Effect of cocoa and tea intake on blood pressure. Arch Intern Med 2007, 167:626-634.

13. Stensvold I, Tverdal A, Solvoll K, Foss O: Tea consumption. Relationship to cholesterol, blood pressure, and cornary and total mortality. Prev Med 1992, 21:546-553.

14. Bogdanski P, Suliburska J, Szulinska M, Stepien M, Pupek-Musialik D, Jablecka A: Green tea extract reduces blood pressure, inflammatory biomarkers, and oxidative stress and improves parameters associated with insulin resistance in obese, hypertensive patients. Nutr Res 2012, 32:421-427.

15. Meri P, Nantz BS: Green tea extract \& blood pressure. Nutr Res 2008, 27:3.

16. Potenza MA, Marasciulo FL, Tarquinio M, Tiravanti E, Colantuono G, Federici A, Kim J-a, Quon MJ, Montagnani M: EGCG, a green tea polyphenol, improves endothelial function and insulin sensitivity, reduces blood pressure, and protects against myocardial I/R injury in SHR. Am J Physiol 2007, 292:1378-1387.

17. Li HL, Huang Y, Zhang CN, Liu G, Wei YS, Wang AB, Liu YQ, Hui RT, Wei C, Williams GM, Liu DP, Liang CC: Epigallocathechin-3 gallate inhibits cardiac hypertrophy through blocking reactive oxidative species-dependent and -independent signal pathways. Free Radic Biol Med 2006, 40:1756-1775.

18. Yang Y-C, Lu F-H, Wu J-S, Wu C-H, Chang C-J: The protective effect of habitual tea consumption on hypertension. Arch Intern Med 2004, 164:1534-1540.

19. Hodgson JM, Devine A, Puddey IB, Chan SY, Beilin L, Prince RL: Tea intake is inversely related to blood pressure in older women. J Nutr 2003, 133:2883-2886 
20. Yokozawa T, Oura H, Sakanaka S, Ishigaki S, Kim M: Depressor effect of tannin in green tea on rats with renal hypertension. Biosci Biotechnol Biochem 1994, 58:855-858.

21. Abe Y, Umemura S, Sugimoto K-i, Hirawa N, Kato Y, Yokoyama N, Yokoyama $T$, Iwai J, Ishii M: Effect of green tea rich in aminobutyric acid on blood pressure of dahl salt-sensitive rats. Am J Hypertens 1995, 8:74-79.

22. Hodgson JM, Croft KD, Woodman RJ, Puddey IB, Fuchs D, Draijer R, Lukoshkova E, Head GA: Black tea lowers the rate of blood pressure variation: a randomized controlled trial. Am J Clin Nutr 2013, 97:943-950.

23. Hodgson JM, Puddey IB, Woodman RJ: Effects of black tea on blood pressure: A randomized controlled trial. Arch Intern Med 2012, 172:186-188.

24. Hodgson JM, Burke $V$, Puddey IB: Acute effects of tea on fasting and postprandial vascular function and blood pressure in humans. $J$ Hypertens 2005, 23:47-54

25. Son JT, Lee E: Effects of green tea ingestion on postprandial drops in blood pressure in older adults. J Gerontol Nurs 2012, 38:30-38.

26. Duffy SJ, Keaney JF Jr, Holbrook M, Gokce N, Swerdloff PL, Frei B, Vita JA: Short- and long-term black tea consumption reverses endothelial dysfunction in patients with coronary artery disease. Circulation 2001, 104:151-156.

27. Bingham SA, Vorster H, Jerling JC, Magee E, Mulligan A, Runswick SA, Cummings $\mathrm{JH}$ : Effect of black tea drinking on blood lipids, blood pressure and aspects of bowel habit. Br J Nutr 1997, 78:41-55.

28. Hodgson JM, Puddey IB, Burke V, Beilin LJ, Jordan N: Effects on blood pressure of drinking green and black tea. J Hypertens 1999, 17:457.

29. Shi Z, Luscombe-Marsh ND, Wittert GA, Yuan B, Dai Y, Pan X, Taylor AW Monosodium glutamate is not associated with obesity or a greater prevalence of weight gain over 5 years: findings from the Jiangsu Nutrition Study of Chinese adults. Br J Nutr 2010, 104:457-463.

30. Shi Z, Yuan B, Qi L, Dai Y, Zuo H, Zhou M: Zinc intake and the risk of hyperglycemia among Chinese adults: the prospective Jiangsu Nutrition Study(JIN). J Nutr Health Aging 2010, 14:332-335.

31. Shi Z, Zhou M, Yuan B, Qi L, Dai Y, Luo Y: Iron intake and body iron stores, anaemia and risk of hyperglycaeia among Chinese adults: the prospective Jiangsu Nutrition Study. Public Health Nutr 2010, 13:1319-1327.

32. Zhao $W$, Hasegawa $K$, Chen J: The use of food frequency questionnaires for various purposes in China. Public Health Nutr 2002, 5:829-833.

33. Li YP, He YN, Zhai FY: Comparion of assessment of food intakes by using 3 dietary survey methods. Zhonghua Yu Fang Yi Xue Za Zhi 2006, 40:273-280

34. Yang Y: Chinese Food Composition Table 2004. Beijing: Peking University Medical Press; 2005.

35. Lang T, Bureau JF, Degoulet P, Salah H, Benattar C: Blood pressure, coffee, tea and tobacco consumption: an epidemiological study in Algiers. Eur Heart J 1983, 4:602-607.

36. Actis-Goretta L, Ottaviani Jl, Fraga CG: Inhibition of angiotensin converting enzyme activity by flavanol-rich foods. J Agric Food Chem 2006, 54:229-234.

37. Loke WM, Hodgson JM, Proudfoot JM, McKinley AJ, Puddey IB, Croft KD: Pure dietary flavonoids quercetin and (-)-epicatechin augment nitric oxide products and reduce endothelin-1 acutely in healthy men. Am J Clin Nutr 2008, 88:1018-1025.

38. Lim D-Y, Lee E-S, Park H-G, Kim B-C, Hong S-P, Lee E-B: Comparison of green tea extract and epigallocatechin gallate on blood pressure and contractile responses of vascular smooth muscle of Rats. Arch Pharm Res 2003, 26:214-223.

39. Zhong Y, Chiou Y-S, Pan M-H, Shahidi F: Anti-inflammatory activity of lipophilic epigallocatechin gallate (EGCG) derivatives in LPS-stimulated murine macrophages. Food Chem 2012, 134:742-748.

40. Harrison DG, Guzik TJ, Lob HE, Madhur MS, Marvar PJ, Thabet SR, Vinh A Weyand CM: Inflammation, immunity, and hypertension. Hypertension 2011, 57:132-140.

41. Cutler RG: Antioxidants and aging. Am J Clin Nutr 1991, 53:373S-379S.

42. Ras RT, Zock PL, Draijer R: Tea consumption enhances endothelialdependent vasodilation; a meta-analysis. PLoS One 2011, 6:1-9.

43. Damasceno MMC, De Araújo MF, Roberto WJF, Zanetti ML: The association between blood pressure in adolescents and the consumption of fruits, vegetables and fruit juice - an exploratory study. J Clin Nurs 2011, 20:1553-1560
44. De Wardener HE, MacGregor GA: Sodium and blood pressure. Curr Opin Cardiol 2002, 17:360

45. Denton D, Weisinger R, Mundy NI, Wickings EJ, Dixson A, Moisson P, Pingard AM, Shade R, Carey D, Ardaillou R: The effect of increased salt intake on blood pressure of chimpanzees. Nat Med 1995, 1:1009-1016.

46. Guan X, Qiu C: Chinese tea consumption. China Tea 2011, 33:13-14.

47. China Department of Agriculture: Chinese tea production and consumption. China Tea 2008, 6:4-6.

48. Kim Y, Goodner KL, Park J-D, Choi J, Talcott ST: Changes in antioxidant phytochemicals and volatile composition of Camellia sinensis by oxidation during tea fermentation. Food Chem 2011, 129:1331-1342.

49. Li Q, Hsia J, Yang G: Prevalence of smoking in China in 2010. N Engl J Med 2011, 364:2469-2470.

50. Yang SH, Dou KF, Song WJ: Prevalence of diabetes among men and women in China. N Engl J Med 2010, 362:2425-2426.

doi:10.1186/1475-2891-13-98

Cite this article as: Tong et al:: Tea consumption is inversely related to 5 -year blood pressure change among adults in Jiangsu, China: a crosssectional study. Nutrition Journal 2014 13:98.

\section{Submit your next manuscript to BioMed Central and take full advantage of:}

- Convenient online submission

- Thorough peer review

- No space constraints or color figure charges

- Immediate publication on acceptance

- Inclusion in PubMed, CAS, Scopus and Google Scholar

- Research which is freely available for redistribution

Submit your manuscript at www.biomedcentral.com/submit
C) Biomed Central 